\title{
Kidney disease and COVID-19 disease severity—systematic review and meta-analysis
}

\author{
Jagmeet Singh ${ }^{1} \cdot$ Preeti Malik $^{2}$ (1) Nidhi Patel ${ }^{3} \cdot$ Suveenkrishna Pothuru ${ }^{4} \cdot$ Avantika Israni $^{5}$. \\ Raja Chandra Chakinala ${ }^{6} \cdot$ Maryam Rafaqat Hussain $^{2} \cdot$ Anusha Chidharla $^{7} \cdot$ Harshil Patel $^{8} \cdot$ Saurabh Kumar Patel $^{9}$. \\ Rizwan Rabbani ${ }^{10}$. Urvish Patel ${ }^{2} \cdot$ Savneek Chugh ${ }^{11} \cdot$ Asim Kichloo $^{12}$
}

Received: 8 February 2021 / Accepted: 16 April 2021 / Published online: 23 April 2021

(c) The Author(s), under exclusive licence to Springer Nature Switzerland AG 2021

\begin{abstract}
We aimed to identify prevalence and association of comorbid chronic kidney disease (CKD), acute kidney injury (AKI) and utilization prevalence of continuous renal replacement therapy (CRRT) in COVID-19-hospitalized patients as a function of severity status. With the ongoing struggle across the globe to combat COVID-19 disease, published literature has described the role of kidney disease in COVID-19 patients based on single/multicenter experiences across the globe. We extracted data from observational studies describing comorbid CKD, AKI and CRRT and outcomes and severity of COVID-19-hospitalized patients from December 1, 2019-August 20, 2020 following PRISMA guidelines. Severity of COVID-19 includes intensive care unit admission, oxygen saturation $<90 \%$, invasive mechanical ventilation utilization, in-hospital admission and mortality. Meta-analysis was performed using a random-effects model to calculate pooled estimates, and forest plots were created. In total, 29 studies with 15,017 confirmed COVID-19 patients were included. The overall prevalence of AKI was 11.6\% [(430/3693)], comorbid CKD 9.7\% [(1342/13,728)] and CRRT 2.58\% [(102/3946)] in our meta-analysis. We also found higher odds of comorbid CKD (pooled OR: $1.70 ; 95 \%$ CI: 1.21-2.40; $p=0.002)$, AKI $(8.28 ; 4.42-15.52 ; p<0.00001)$ and utilization of CRRT (16.90; 9.00-31.74; $p<0.00001)$ in patients with severe COVID-19 disease. Conclusion Our metaanalysis suggests that comorbid CKD, AKI and utilization of CRRT were significantly associated with COVID-19 disease severity. Clinicians should focus on early triaging of COVID-19 patients with comorbid CKD and at risk for AKI to prevent complication and mortality.
\end{abstract}

Keywords COVID-19 $\cdot$ Coronavirus $\cdot$ Kidney disease $\cdot$ Kidney injury $\cdot$ Chronic kidney disease $\cdot$ Continuous renal replacement therapy

\section{Introduction}

COVID-19 is causing catastrophe across the world. As of January 17, 2021, over 93.1 million cases and 2 million deaths have been reported globally [1]. In the past decade, the world has experienced the emergence of three previously unidentified coronaviruses: severe acute respiratory syndrome coronavirus (SARS-CoV) in 2003, Middle East Respiratory Syndrome Coronavirus (MERS-CoV) in 2012 and Coronavirus Disease 2019 (COVID-19 or SARS-CoV-2) in late December, 2019. All these viruses belong to the Coronaviridae, a family of viruses that possess a positive-sense

Preeti Malik

pmalik.ma@gmail.com

Extended author information available on the last page of the article single-stranded RNA genome. Occasionally, the genetic recombination of viruses within random intermediate hosts produces contagious strains that are highly pathogenic to humans. Whereas SARS-CoV-2 is genetically and structurally related to SARS-CoV, it is becoming increasingly clear that it has its own unique features that contributed to the rapid spread around the globe [2].

Although COVID-19 primarily affects the lungs, kidney dysfunction occurs through an unclear and likely multifactorial mechanism. The mechanism of entry is likely facilitated by the angiotensin-converting enzyme-2 (ACE2), cellular transmembrane serine protease 2 (TMPRSS2) and cathepsin L (CTSL) which are highly expressed in kidney tissue $[3,4]$. Additionally, other mechanisms that could lead to tubular necrosis are: sepsis, cytokine storm, shock/ hemodynamic instability, rhabdomyolysis, direct viral 
invasion, nephrotoxic drug-related factors and hypoxia of kidney tissue [3]. More specifically, viral infection could also induce tubular damage through the deposition of the membrane attack complex (MAC) on tubules and infiltration of CD68+ macrophages in the tubule interstitium [3]. Additionally, patients with comorbid chronic kidney disease (CKD) have a higher risk of upper respiratory tract infection and pneumonia due to a persistent pro-inflammatory state and defects in innate and adaptive immunity [2,5]. In a meta-analysis done by Henry et al. it was found that there is a significant association of chronic kidney disease with severe COVID-19 [6].

Treatment of critically ill patients with SARS-COV-2 infection and acute severe renal failure can include continuous renal replacement therapy (CRRT), and a renal replacement method intended to be applied for $24 \mathrm{~h}$ or longer through continuous, slower low efficiency dialysis (SELD), intermittent hemodialysis and peritoneal dialysis [7]. There has been a high utilization of CRRT use among COVID-19 patients who require ICU level of care. A study by Baduashvili et al. found that among patients with COVID-19, about $20 \%$ who had acute respiratory distress syndrome (ARDS) or needed ICU admission received CRRT [8].

Hence, we aim to discuss the effects of acute kidney injury (AKI), comorbid chronic kidney disease (CKD) in COVID-19 severity and also evaluate the prevalence utilization of CRRT in severely ill COVID-19 patients.

\section{Methods}

\section{Endpoint}

The aim of the study is to evaluate the role of the comorbid CKD, AKI in predicting COVID-19 severity and the utilization prevalence of continuous renal replacement therapy (CRRT) in COVID-19-hospitalized patients. We defined severity of disease as intensive care unit (ICU) admission, oxygen saturation $<90 \%$, invasive mechanical ventilation (IMV) utilization, severe disease and in-hospital mortality.

\section{Search strategy and selection criteria}

This meta-analysis adhered to the recommendations of the Preferred Reporting Items for Systematic Reviews and MetaAnalyses (PRISMA) statement [9] and followed the MOOSE checklist [10]. The databases PubMed, Web of Science, Scopus, and medRxiv were searched for eligible studies that described comorbidities, complications, treatment and outcomes of COVID-19 patients following keyword/MESH terms: (COVID-19[Title/Abstract]) OR coronavirus [Title/ Abstract]) OR SARS-CoV-2[Title/Abstract] from December 1, 2019-August 20, 2020. Studies were included in this meta-analysis if they had laboratory confirmed COVID-19 patients with information on comorbid CKD, AKI, CRRT and outcomes of COVID-19-hospitalized patients. We excluded articles: pediatric population, Non-English language, case reports, and case series. Flow diagram of the literature search and study selection process is described in Fig. 1.

\section{Study selection}

Articles were initially screened by titles and abstracts to assess for relevance, and those articles with information on comorbid CKD, AKI, CRRT and outcomes of COVID-19 patients were retrieved. Studies which gave details on outcomes were selected for quantitative analysis. Preeti Malik (PM) and Urvish Patel (UP) independently screened all identified studies and assessed full texts to decide eligibility. Any disagreement was resolved through consensus with Nidhi Patel (NP).

\section{Data collection}

From the studies finally included, we extracted the following variables including comorbid CKD, AKI, CRRT and outcomes. Details on disease severity like ICU vs. non-ICU admission, severe vs non-severe disease, IMV vs no-IMV use, oxygen saturation $<90 \%$ versus $>90 \%$, in-hospital mortality vs discharged alive and survivors were collected using prespecified data collection sheet (Table 1).

\section{Statistical Analysis}

Review Manager version 5.4 (The Nordic Cochrane Centre, The Cochrane Collaboration, Copenhagen, Denmark) was used for conducting the meta-analysis. The Mantel-Haenszel formula was used to obtain pooled odds ratios (ORs) for dichotomous variables along with its $95 \%$ confidence intervals $(95 \% \mathrm{CI})$ irrespective of heterogeneity. The $I^{2}$ statistic was used to assess statistical heterogeneity, and value $>50 \%$ was considered significant heterogeneity. A 2-tailed $p$ value of $<0.05$ was considered statistically significant. Publication bias was assessed visually using funnel plots (supplemental file). The Newcastle-Ottawa scale (NOS) [11] was used to assess the quality and bias in the included studies, which rates selection, comparability and outcome (supplemental file). Majority of the studies were assessed to be of moderate quality. Sensitivity analysis was performed to assess the effect of publication bias and heterogeneity by excluding outlying studies on the funnel plot. The pooled-OR and 95\% CI are represented in the form of forest plots. 
Fig. 1 Flow diagram of literature search and study selection process of kidney disease and COVID-19 severity
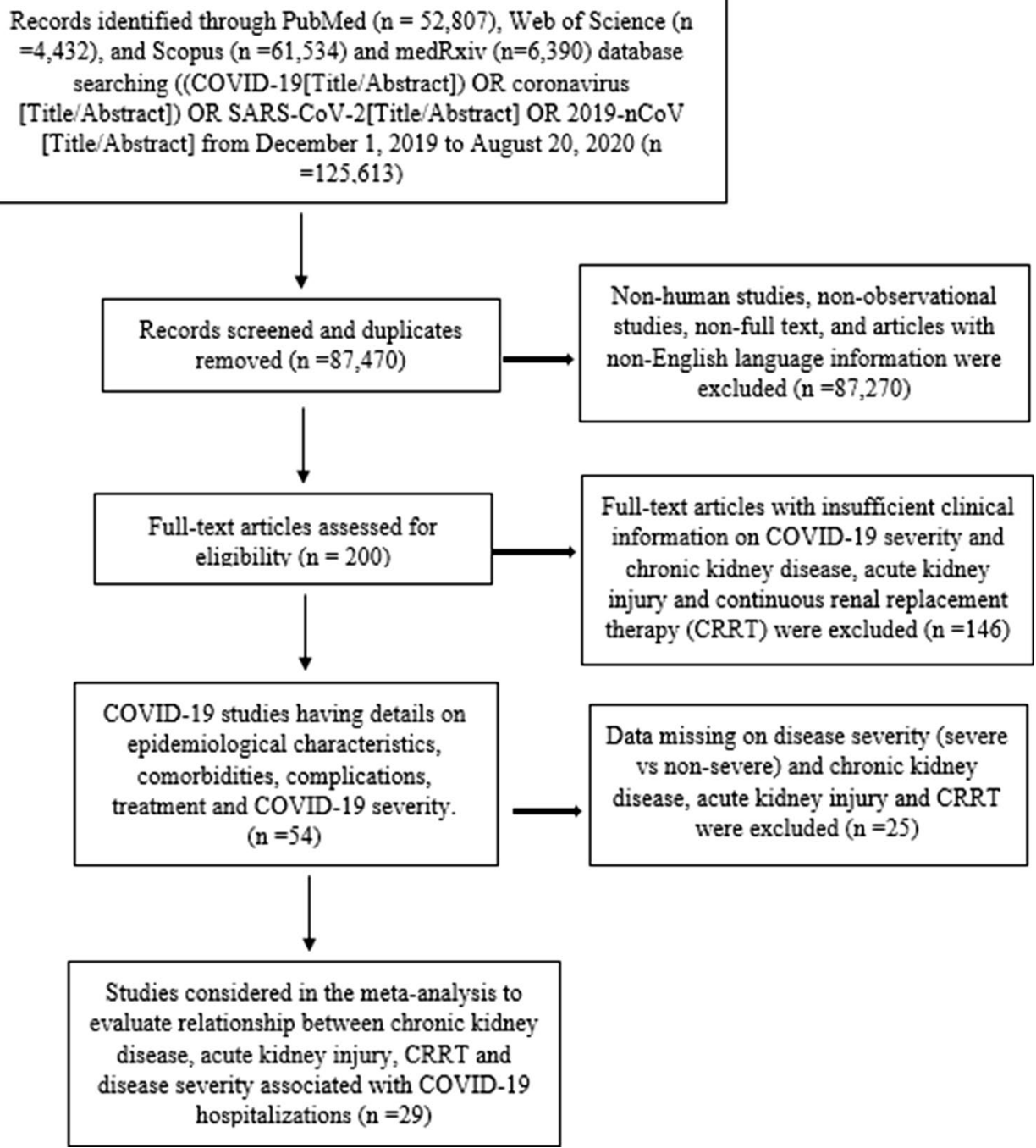

Data missing on disease severity (severe vs non-severe) and chronic kidney disease, acute kidney injury and CRRT were excluded $(n=25)$

\section{Results}

We found 200 full text articles eligible for study after removing duplicated articles, non-human studies, non-observational studies and articles with non-English language. After detailed assessment and considering strict inclusion and exclusion criteria, as of August 20, 2020, we included 29 observational studies with 15,017 confirmed cases of COVID-19 patients detailing comorbid CKD, AKI, CRRT and disease severity. Out of these 29 studies, 20 studies were performed in china, 6 in the USA, 1 each in South Korea, Poland and Iran, respectively. Table 1 describes the study characteristics including the first author's last name, publication month and year, country of origin, sample size, study design, and outcomes and comorbid CKD, AKI and CRRT assessed in that individual study.

The overall prevalence of AKI was $11.6 \%$ (430/3693), comorbid CKD was 9.7\% (1342/13,728), CRRT utilization was $2.58 \%(102 / 3946)$ in our meta-analysis.

\section{Comorbid chronic kidney disease (CKD)}

Total of 22 studies reported data on comorbid CKD with severity giving a total sample size of 13,728 COVID-19 patients for evaluation. Meta-analysis showed that comorbid CKD had 1.7 times higher odds of having severe COVID19 compared to non-severe (pooled OR: 1.70; 95\%CI: $1.21-2.40 ; p=0.002)$ with $64 \%$ heterogeneity in the data ( $p<0.0001)$ (Fig. 2). In order to account for heterogeneity between studies, we performed a sensitivity analysis by eliminating the Yang et al. study on funnel plots. Results after sensitivity analysis also showed significant pooled OR of 1.97 (95\%CI:1.61-2.42; $p<0.00001)$ with $20 \%$ heterogeneity in the data $(p=0.20)$ (Supplemental File).

\section{Acute kidney injury (AKI)}

Sixteen studies with a sample size of 3693 patients were reported the association between AKI and disease severity. 
Table 1 Study characteristics, design, outcome, kidney disease and continuous renal replacement therapy (CRRT) described in individual study

\begin{tabular}{|c|c|c|c|c|c|c|c|}
\hline Study & Country & Sample size (N) & $\begin{array}{l}\text { Mean/ } \\
\text { median age } \\
\text { (years) }\end{array}$ & Males $n(\%)$ & Study design & Outcomes & Kidney disease \\
\hline Huang et al. [12] & China & 41 & 49 & $30(73)$ & $\begin{array}{l}\text { Prospective single } \\
\text { center }\end{array}$ & $\begin{array}{l}\text { ICU versus Non- } \\
\text { ICU }\end{array}$ & $\begin{array}{l}\text { AKI } \\
\text { CRRT }\end{array}$ \\
\hline Guan et al. [13] & China & 1099 & 47 & $637(58)$ & $\begin{array}{l}\text { Retrospective multi- } \\
\text { center }\end{array}$ & $\begin{array}{l}\text { Severe versus non- } \\
\text { severe* }\end{array}$ & $\begin{array}{l}\text { AKI } \\
\text { CRRT } \\
\text { CKD }\end{array}$ \\
\hline Wang et al. [14] & China & 138 & 56 & $75(54)$ & $\begin{array}{l}\text { Retrospective single } \\
\text { center }\end{array}$ & $\begin{array}{l}\text { ICU versus Non- } \\
\text { ICU }\end{array}$ & $\begin{array}{l}\text { AKI } \\
\text { CRRT } \\
\text { CKD }\end{array}$ \\
\hline Zhang et al. [15] & China & 140 & 57 & $71(50)$ & $\begin{array}{l}\text { Retrospective single } \\
\text { center }\end{array}$ & $\begin{array}{l}\text { Severe versus non- } \\
\text { severe** }\end{array}$ & CKD \\
\hline Yang et al. [16] & China & 52 & 59.7 & $35(67)$ & $\begin{array}{l}\text { Retrospective single } \\
\text { center }\end{array}$ & $\begin{array}{l}\text { Non-survivor versus } \\
\text { Survivor }\end{array}$ & $\begin{array}{l}\text { AKI } \\
\text { CRRT }\end{array}$ \\
\hline $\begin{array}{l}\text { Mo et al. Mar } 2020 \\
\text { [17] }\end{array}$ & China & 155 & 54 & $86(55)$ & $\begin{array}{l}\text { Retrospective single } \\
\text { center }\end{array}$ & $\begin{array}{l}\text { General versus } \\
\text { Refractory\# }\end{array}$ & CKD \\
\hline Wang et al. [18] & China & 339 & 69 & $166(48)$ & $\begin{array}{l}\text { Retrospective single } \\
\text { center }\end{array}$ & $\begin{array}{l}\text { Dead versus Sur- } \\
\text { vival }\end{array}$ & $\begin{array}{l}\text { AKI } \\
\text { CKD }\end{array}$ \\
\hline Ruan et al. [19] & China & 150 & 67 vs. 50 & $102(68)$ & $\begin{array}{l}\text { Retrospective multi- } \\
\text { center }\end{array}$ & $\begin{array}{l}\text { Died versus Dis- } \\
\text { charged }\end{array}$ & $\begin{array}{l}\text { AKI } \\
\text { CRRT } \\
\text { CKD }\end{array}$ \\
\hline Zhou et al. [20] & China & 191 & 56 & $119(62)$ & $\begin{array}{l}\text { Retrospective multi- } \\
\text { center }\end{array}$ & $\begin{array}{l}\text { Non-survivor versus } \\
\text { Survivor }\end{array}$ & $\begin{array}{l}\text { AKI } \\
\text { CRRT } \\
\text { CKD }\end{array}$ \\
\hline Chen et al. [21] & China & 21 & 56 & $17(81)$ & $\begin{array}{l}\text { Retrospective single } \\
\text { center }\end{array}$ & $\begin{array}{l}\text { Severe versus Mod- } \\
\text { erate }{ }^{* *}\end{array}$ & AKI \\
\hline Qin et al. [22] & China & 452 & 58 & $235(52)$ & $\begin{array}{l}\text { Retrospective single } \\
\text { center }\end{array}$ & $\begin{array}{l}\text { Severe versus non- } \\
\text { severe** }\end{array}$ & CKD \\
\hline Zhao et al. [23] & China & 91 & 46 & $49(54)$ & $\begin{array}{l}\text { Retrospective single } \\
\text { center }\end{array}$ & Severe versus Mild ${ }^{\text {II }}$ & $\begin{array}{l}\text { AKI } \\
\text { CRRT } \\
\text { CKD }\end{array}$ \\
\hline Goyal et al. [24] & USA & 393 & 62.2 & $238(61)$ & $\begin{array}{l}\text { Retrospective multi- } \\
\text { center }\end{array}$ & IMV versus No IMV & $\begin{array}{l}\text { CRRT } \\
\text { CKD }\end{array}$ \\
\hline Paranjpe et al. [25] & USA & 1078 & 65 & $627(58)$ & $\begin{array}{l}\text { Retrospective multi- } \\
\text { center }\end{array}$ & $\begin{array}{l}\text { In-hospital mortality } \\
\text { versus Discharged } \\
\text { alive }\end{array}$ & CKD \\
\hline Wan et al. [26] & China & 135 & 47 & $72(53)$ & $\begin{array}{l}\text { Retrospective single } \\
\text { center }\end{array}$ & $\begin{array}{l}\text { Severe versus } \\
\text { Mild** }\end{array}$ & $\begin{array}{l}\text { AKI } \\
\text { CRRT }\end{array}$ \\
\hline Zheng et al. [27] & China & 34 & 66 & $23(68)$ & $\begin{array}{l}\text { Retrospective single } \\
\text { center }\end{array}$ & $\begin{array}{l}\text { IMV versus No } \\
\text { IMV }^{\mathbb{I I I}}\end{array}$ & $\begin{array}{l}\text { AKI } \\
\text { CRRT } \\
\text { CKD }\end{array}$ \\
\hline Hong et al. [28] & South Korea & 98 & 55.4 & $38(39)$ & $\begin{array}{l}\text { Retrospective single } \\
\text { center }\end{array}$ & $\begin{array}{l}\text { ICU versus Non- } \\
\text { ICU }\end{array}$ & $\begin{array}{l}\text { AKI } \\
\text { CRRT }\end{array}$ \\
\hline Nowak et al. [29] & Poland & 169 & 64 & $87(51)$ & $\begin{array}{l}\text { Retrospective single } \\
\text { center }\end{array}$ & $\begin{array}{l}\text { Non-survivor versus } \\
\text { Survivor }\end{array}$ & $\begin{array}{l}\text { AKI } \\
\text { CRRT } \\
\text { CKD }\end{array}$ \\
\hline Mikami et al. [30] & USA & 2820 & 76 vs. 62 & $1611(41)$ & $\begin{array}{l}\text { Retrospective multi- } \\
\text { center }\end{array}$ & $\begin{array}{l}\text { Non-survivor versus } \\
\text { Survivor }\end{array}$ & CKD \\
\hline Marcello et al. [31] & USA & 5010 & 61 & $3055(61)$ & $\begin{array}{l}\text { Retrospective multi- } \\
\text { center }\end{array}$ & $\begin{array}{l}\text { Died versus Dis- } \\
\text { charged }\end{array}$ & CKD \\
\hline $\begin{array}{l}\text { Shahriarirad et al. } \\
\text { [32] }\end{array}$ & Iran & 113 & 53.75 & $71(63)$ & $\begin{array}{l}\text { Retrospective multi- } \\
\text { center }\end{array}$ & $\begin{array}{l}\text { Severe versus non- } \\
\text { severe* }\end{array}$ & CKD \\
\hline Wang et al. [33] & China & 275 & 49 & $128(46)$ & $\begin{array}{l}\text { Retrospective single } \\
\text { center }\end{array}$ & $\begin{array}{l}\text { Severe versus non- } \\
\text { severe** }\end{array}$ & $\begin{array}{l}\text { CKD } \\
\text { CRRT }\end{array}$ \\
\hline
\end{tabular}


Table 1 (continued)

\begin{tabular}{|c|c|c|c|c|c|c|c|}
\hline Study & Country & Sample size (N) & $\begin{array}{l}\text { Mean/ } \\
\text { median age } \\
\text { (years) }\end{array}$ & Males $n(\%)$ & Study design & Outcomes & Kidney disease \\
\hline Zhang et al. [34] & China & 221 & 55 & $108(49)$ & $\begin{array}{l}\text { Retrospective single } \\
\text { center }\end{array}$ & $\begin{array}{l}\text { Severe versus non- } \\
\text { severe** }\end{array}$ & $\begin{array}{l}\text { AKI } \\
\text { CRRT } \\
\text { CKD }\end{array}$ \\
\hline Suleyman et al. [35] & USA & 463 & 57.5 & $204(44)$ & $\begin{array}{l}\text { Retrospective single } \\
\text { center }\end{array}$ & $\begin{array}{l}\text { Hospitalized versus } \\
\text { Discharged }\end{array}$ & CKD \\
\hline Wang et al. [36] & China & 344 & 64 & $179(52)$ & $\begin{array}{l}\text { Retrospective single } \\
\text { center }\end{array}$ & $\begin{array}{l}\text { Non-survivor versus } \\
\text { Survivor }\end{array}$ & AKI \\
\hline Li et al. [37] & China & 548 & 60 & $279(51)$ & $\begin{array}{l}\text { Retrospective single } \\
\text { center }\end{array}$ & $\begin{array}{l}\text { Severe versus non- } \\
\text { severe** }\end{array}$ & $\begin{array}{l}\text { CRRT } \\
\text { CKD }\end{array}$ \\
\hline $\mathrm{Xu}$ et al. [38] & China & 239 & 62 & $143(60)$ & $\begin{array}{l}\text { Retrospective single } \\
\text { center }\end{array}$ & $\begin{array}{l}\text { Non-survivor versus } \\
\text { Survivor }\end{array}$ & $\begin{array}{l}\text { AKI } \\
\text { CRRT }\end{array}$ \\
\hline Ferguson et al. [39] & USA & 72 & 60.4 & $38(53)$ & $\begin{array}{l}\text { Retrospective multi- } \\
\text { center }\end{array}$ & $\begin{array}{l}\text { ICU versus Non- } \\
\text { ICU }\end{array}$ & $\begin{array}{l}\text { AKI } \\
\text { CRRT } \\
\text { CKD }\end{array}$ \\
\hline Yang et al. [40] & China & 136 & 56 & $66(48)$ & $\begin{array}{l}\text { Retrospective multi- } \\
\text { center }\end{array}$ & $\begin{array}{l}(\text { Severe }+ \text { Critical }) \\
\text { versus Mild }\end{array}$ & CKD \\
\hline Total & 15,017 & & & & & & \\
\hline
\end{tabular}

IVIG: intravenous immunoglobulin; ARDS: acute respiratory distress syndrome; IMV: invasive mechanical ventilation; CKD: comorbid chronic kidney disease; AKI: acute kidney injury; CRRT: continuous renal replacement therapy

*Using the American Thoracic Society guidelines for community-acquired pneumonia

**World Health Organization and the National Health Commission of China interim guidelines defined disease severity and improvement as follows: mild cases: the mild clinical symptoms and no pneumonia in imaging. Moderate cases: symptoms like fever and respiratory tract symptoms, etc., and pneumonia can be seen in imaging. Severe cases: meeting any of the following-respiratory distress, respiratory rate $\geq 30$ breaths/min; $\mathrm{SpO} 2 \leq 93 \%$ at rest; and $\mathrm{PaO} 2 / \mathrm{FIO} 2 \leq 300$. Patients with $>50 \%$ lesion progression within $24-48 \mathrm{~h}$. Critical/extremely severe cases: if they have one of the following: respiratory failure requiring mechanical ventilation, shock, and other organ failure requiring ICU treatment

\#General COVID-19 was defined according to following criteria: (i) obvious alleviation of respiratory symptoms (e.g., cough, chest distress and breath shortness) after treatment; (ii) maintenance of normal body temperature for $\geq 3$ days without the use of corticosteroid or antipyretics; (iii) improvement in radiological abnormalities on chest CT or X-ray after treatment; (iv) a hospital stay of $\leq 10$ days. Otherwise, it was classified as refractoryCOVID-19

${ }^{\mathbb{I}}$ Not mentioned

III Non-invasive mechanical ventilation (NIV) included nasal oxygen therapy, mask oxygen inhalation; high-flow nasal cannula (HFNC).

Meta-analysis of all 16 studies showed that AKI had higher odds of severe disease compared to non-severe with a pooled OR of 8.28 (95\%CI: $4.42-15.52 ; p<0.00001)$ and $73 \%$ heterogeneity between studies $(p<0.00001)$ (Fig. 3). Sensitivity analysis was performed by eliminating the 3 outlying studies (Wan et al., Wang et al. and Li et al.) on funnel plots which also showed significant pooled OR of 8.44 (95\%CI: $5.90-12.08 ; p<0.00001)$ with $0 \%$ heterogeneity in the data $(p=0.82$ (Supplemental File).

\section{Continuous renal replacement therapy (CRRT)}

Seventeen out of total 29 studies reported data on CRRT utilization based on severity of COVID-19 including 3946 patients. We found that utilization of CRRT was higher in COVID-19 patients with severe disease (pooled OR: 16.90; 95\% CI: 9.00-31.74; $p<0.00001$ ), and no significant heterogeneity between studies ( $\left.p=0.95 ; I^{2}=0 \%\right)$ (Fig. 4).

\section{Discussion}

Although COVID-19 primarily affects the lungs, kidney dysfunction is also observed in a large population of COVID19 patients. In our meta-analysis of 29 studies with 15,017 patients, we found that comorbid CKD, AKI and CRRT utilization was higher in patients with severe COVID-19 disease. Incidence of AKI in COVID-19 patients was found to be up to $25 \%$ among critically ill patients with underlying comorbidities [41]. The exact mechanism by which SARSCoV-2 causes renal damage is not fully known, but studies have shown that cellular components required for virus entry such as angiotensin-converting enzyme 2 (ACE2), cellular transmembrane serine protease 2 (TMPRSS2) and cathepsin L (CTSL) are highly expressed in kidneys [4]. Specifically, the co-expression of ACE2 and TMPRSS is reported to be high in podocytes and the proximal straight tubule, suggesting a favorable condition for the localization of the virus. 


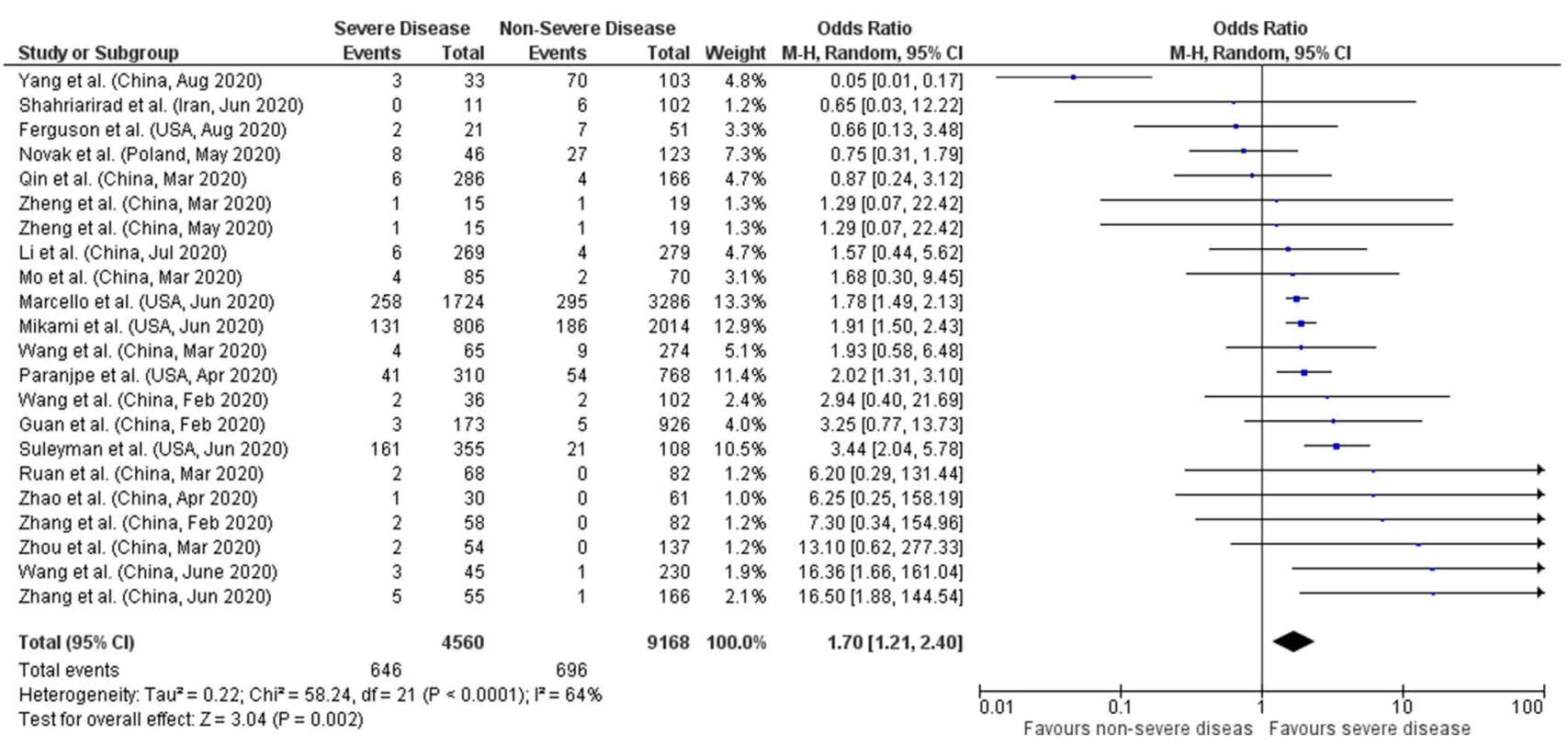

Fig. 2 Forest plot of comorbid CKD and COVID-19 severity

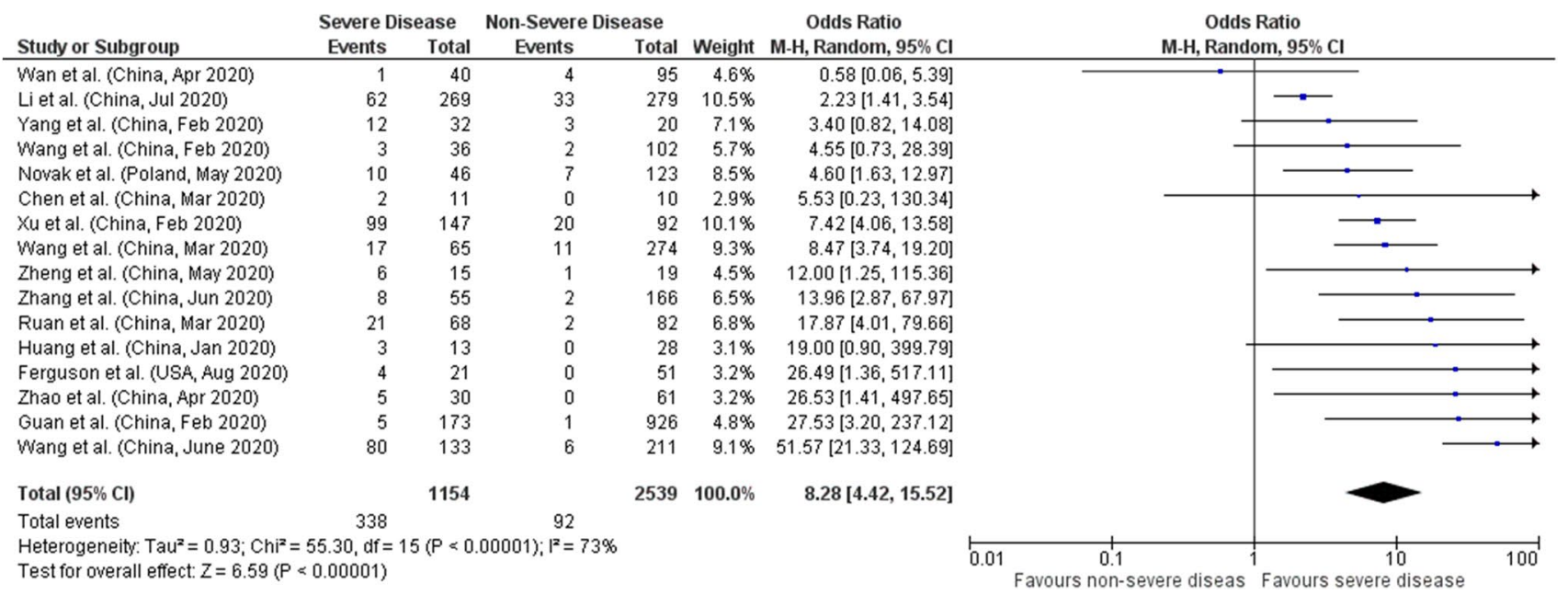

Fig. 3 Forest plot of acute kidney injury (AKI) and COVID-19 severity

The mechanism of the immune response induced by SARSCoV-2 is broken up into two phases: 1) an initial specific adaptive immune response and 2) uncontrolled inflammation. The adaptive response helps to prevent the progression of the virus and attempts to eliminate the virus; however, when this response fails, an uncontrolled inflammatory response ensues, propagating a cytokine storm which may promote apoptosis and necrosis of T cells [3]. These components are speculated to lead to renal inflammation, increased vascular permeability, cardiomyopathy and volume depletion which all lead to cardiorenal syndrome type 1 [42].

Several studies have found a significant association between kidney failure and death. Cheng et al. (2020) found that patients with kidney disease on admission (elevated baseline serum creatinine) were more likely to be admitted to the intensive care unit and undergo ventilation and have a higher risk of deterioration [5]. In addition, the study shows that indicators of kidney involvement such as: elevated baseline serum creatinine, elevated baseline blood urea nitrogen, proteinuria and hematuria were associated with higher risk of in-hospital death after adjusting for confounders such as age, sex, disease severity, comorbidity and leukocyte count [5]. In another study conducted to explore the clinical courses of critically ill COVID-19 patients with and without pre-existing kidney disease and in-hospital outcomes (which included in-hospital mortality, respiratory failure, 


\begin{tabular}{|c|c|c|c|c|c|c|c|c|c|c|c|}
\hline \multirow[b]{2}{*}{ Study or Subgroup } & \multicolumn{2}{|c|}{ Severe DIsease } & \multicolumn{2}{|c|}{ Non-Severe Disease } & \multirow[b]{2}{*}{ Weight } & \multirow{2}{*}{$\begin{array}{l}\text { Odds Ratio } \\
\text { M-H, Random, } 95 \% \mathrm{Cl}\end{array}$} & \multirow{2}{*}{\multicolumn{5}{|c|}{$\begin{array}{c}\text { Odds Ratio } \\
\text { M-H, Random, } 95 \% \mathrm{Cl} \\
\end{array}$}} \\
\hline & Events & Total & Events & Total & & & & & & & \\
\hline Ferguson et al. (USA, Aug 2020) & 4 & 21 & 0 & 51 & $4.5 \%$ & $26.49[1.36,517.11]$ & & & & & $\longrightarrow$ \\
\hline Goyal et al. (USA, Apr 2020) & 17 & 130 & 1 & 263 & $9.6 \%$ & $39.42[5.18,299.76]$ & & & & & $\longrightarrow$ \\
\hline Guan et al. (China, Feb 2020) & 9 & 173 & 0 & 926 & $4.9 \%$ & $107.01[6.20,1847.50]$ & & & & & $\longrightarrow$ \\
\hline Hong et al. (South Korea, May 2020) & 3 & 13 & 0 & 85 & $4.3 \%$ & $57.00[2.75,1181.76]$ & & & & & \\
\hline Huang et al. (China, Jan 2020) & 3 & 13 & 0 & 28 & $4.3 \%$ & $19.00[0.90,399.79]$ & & & & & \\
\hline Li et al. (China, Jul 2020) & 2 & 269 & 0 & 279 & $4.3 \%$ & $5.22[0.25,109.32]$ & & & & & \\
\hline Novak et al. (Poland, May 2020) & 1 & 46 & 0 & 123 & $3.8 \%$ & $8.14[0.33,203.52]$ & & & & & \\
\hline Ruan et al. (China, Mar 2020) & 5 & 68 & 0 & 82 & $4.7 \%$ & $14.29[0.78,263.26]$ & & & & & \\
\hline Wan et al. (China, Apr 2020) & 4 & 40 & 1 & 95 & $8.0 \%$ & $10.44[1.13,96.62]$ & & & & & \\
\hline Wang et al. (China, Feb 2020) & 2 & 36 & 0 & 102 & $4.2 \%$ & $14.86[0.70,317.07]$ & & & & & \\
\hline Wang et al. (China, June 2020) & 6 & 45 & 0 & 230 & $4.7 \%$ & $75.86[4.19,1373.44]$ & & & & & \\
\hline Xu et al. (China, Jul 2020) & 11 & 147 & 1 & 92 & $9.3 \%$ & $7.36[0.93,57.99]$ & & & & & \\
\hline Yang et al. (China, Feb 2020) & 8 & 32 & 1 & 20 & $8.5 \%$ & $6.33[0.73,55.15]$ & & & & & \\
\hline Zhang et al. (China, Jun 2020) & 4 & 55 & 1 & 166 & $8.1 \%$ & $12.94[1.41,118.40]$ & & & & & \\
\hline Zhao et al. (China, Apr 2020) & 3 & 30 & 0 & 61 & $4.4 \%$ & $15.65[0.78,313.52]$ & & & & & \\
\hline Zheng et al. (China, May 2020) & 4 & 15 & 1 & 19 & $7.4 \%$ & $6.55[0.65,66.35]$ & & & & & \\
\hline Zhou et al. (China, Mar 2020) & 10 & 54 & 0 & 137 & $4.9 \%$ & $64.89[3.73,1129.76]$ & & & & & \\
\hline Total $(95 \% \mathrm{Cl})$ & & 1187 & & 2759 & $100.0 \%$ & $16.90[9.00,31.74]$ & & & & & \\
\hline Total events & 96 & & 6 & & & & & & & & \\
\hline $\begin{array}{l}\text { Heterogeneity: } \operatorname{Tau}^{2}=0.00 ; \mathrm{Chi}^{2}=8.0 \\
\text { Test for overall effect: } Z=8.80 \text { (P }<0 \text {. }\end{array}$ & $\begin{array}{l}d f=16(F \\
0001)\end{array}$ & $0.95) ; 1$ & & & & & 0.005 & 0.1 & I & & 200 \\
\hline
\end{tabular}

Fig. 4 Forest plot of utilization of CRRT and COVID-19 severity

shock, ventricular arrhythmia/ cardiac arrest, thromboembolic event, major bleed and acute liver injury), it was found that dialysis patients had a shorter time from symptom onset to ICU admission and more dialysis patients (25\%) reported altered mental status than those with comorbid CKD and no kidney disease. Additionally, $50 \%$ of dialysis and CKD patients died within 28 days of ICU admission versus 35\% of patients without pre-existing kidney disease [43]. Dialysis patients also had a higher risk of 28-day in-hospital death [43]. In addition to the increased risk for poor prognosis with pre-existing kidney pathologies, AKI is a well-recognized factor of poor prognosis leading greater use of healthcare resources [41, 44]. COVID-19 patients with AKI had higher severe infection and case-fatality rates. Shao et al. found that the incidence of AKI in COVID-19 patients was 10\%, mainly indicated by elevated serum creatinine and BUN levels evident in patients with severe infection [45]. Other studies have also shown that elevated serum creatinine and BUN levels were independent risk factors for in-hospital death $[5,45]$.

Various studies have reported that 1.5-9\% of COVID19 patients require CRRT and particularly $5.6-23 \%$ of critically ill patients received CRRT [12, 13, 20, 46, 47]. There are both renal and non-renal indications for the use of CRRT in COVID-19 patients. Renal indications include severe AKI with hemodynamic instability. Nonrenal indications include complications with severe ARDS and conditions uncontrolled with conservative medical treatment including persistent inflammatory fever, refractory hypernatremia, volume overload or urine output and diuretic resistance [48]. Additionally, a study by Raina et al. suggests that CRRT can be utilized to non-selectively clear inflammatory mediators and may be able to correct fluid overload, adjust immune stability and manage solute levels to provide hemodynamic stability [49]. Furthermore, studies have demonstrated that CRRT reduces extravascular fluid in the lungs, achieves acid-base balance, reduces ventilation pressures, increases the lung oxygenation number and provides less invasive ventilation of $\mathrm{CO} 2[50,51]$. Therefore, it is reasonable to postulate that the initiation of CRRT in COVID-19 patients suffering from respiratory insufficiency could be beneficial. A study by Yang et al. found that among 52 critically ill adult patients with COVID-19 pneumonia admitted to the ICU, 12 (23\%) of patients developed AKI and 9 (17\%) required renal replacement therapy [46]. There is not enough strong evidence to support the effect of CRRT in critically ill patients in reducing mortality [52]. Furthermore, a major challenge which the entire world is dealing with in COVID-19 pandemic is the mismatch of resources in supply and demand due to the surge in dialysis units in the hospitals [53]. Hence, it is crucial to aim to maximize the utility of any CRRT circuit in order to conserve supplies. Moreover, clinicians should evaluate overall patients' conditions including patient's level of systemic inflammation, severity and progress of illness and AKI, available resources before giving the choice of CRRT.

\section{Limitations and Strength}

The important limitation of this meta-analysis is the heterogeneity of the included studies due to different definitions of chronic kidney disease, variation in diagnosing criteria and staging of acute kidney injury and definition of disease severity among various countries, reflecting different national and regional healthcare systems. Another possible reason of variability among studies might be due to variation between and within countries in regard to reported 
hospital admission rates of COVID-19 patients, hospitalization policies and for assigning levels of care (e.g., ICU admission, invasive mechanical ventilation). Most of our studies included in analysis are from China, and there may be a chance of overlap of study population and may not be representative of the general population in other countries. Another limitation is we cannot distinguish whether these patients had de novo AKI or AKI superimposed on comorbid CKD. Additionally, the studies have not specified the utilization of CRRT was only for renal disease patients or all COVID-19 patients. Despite these limitations, meta-analysis of 29 studies with 15,017 confirmed COVID-19 patients, we found that AKI, comorbid CKD and utilization of CRRT were significantly associated with COVID-19 severity adding to the existing literature [54-56]. Future prospective studies should focus on the stratification of chronic kidney diseases, causes of acute kidney injury, patterns of injury, duration and course of AKI, which would further help to understand the relation of different kidney disease and their effects on COVID-19.

\section{Conclusion}

To conclude, acute kidney injury (AKI), comorbid CKD and CRRT are not only frequent in COVID-19 but are also associated with disease severity. COVID-19 can affect the kidneys through several mechanisms and is associated with morbidity and mortality then initially thought. Hence, future studies should carefully investigate the cause of kidney injury during COVID-19 infection especially if it is treatment drug related. From a clinical perspective, these findings may help in early triage of COVID-19 patients at risk of AKI due to comorbid CKD or other comorbidities, close monitoring of the occurrence of kidney injury and post-discharge follow-up of COVID-19 patients with AKI and careful use of drugs which can cause renal toxicity in COVID-19 patients. The CRRT application may need to be adjusted to conserve resources in the context of a surge in COVID-19 cases.

Supplementary Information The online version contains supplementary material available at https://doi.org/10.1007/s10238-021-00715-x.

\section{Acknowledgements None}

Author contributions JS and PM helped in conceptualization and methodology; PM, UP and NP curated the data; PM and UP formally analyzed; none acquired the funding; PM, JS, MH, UP, SC and AK investigated the study; PM developed the software; NP, SP, AI, AC, AK validated the study; $\mathrm{PM}$ and $\mathrm{AC}$ administrated the project; JS and AK helped in resources; SC and AK supervised the study; JS, NP, AC, SP, AI, RC, MH, AC, HP, SKP, RR wrote the original draft; PM, UP, $\mathrm{SC}$ and $\mathrm{AK}$ wrote the review and edited.
Funding None.

Data Availability Files for the raw analysis will be made available upon request.

\section{Declaration}

Conflict of interest The authors report no disclosures relevant to the manuscript. The authors declare that there is no conflict of interest.

Informed Consent This review article does not have direct or indirect involvement of human or animal, so permission from IRB or ethics committee was not applicable or required.

\section{References}

1. COVID-19 CORONAVIRUS PANDEMIC. https://www.world ometers.info/coronavirus/\#countries (2020). Accessed 17 January 2020.

2. Tu Y-F, Chien C-S, Yarmishyn AA, Lin Y-Y, Luo Y-H, Lin Y-T, et al. A review of SARS-CoV-2 and the ongoing clinical trials. Int J Mol Sci. 2020. https://doi.org/10.3390/ijms21072657.

3. Benedetti C, Waldman M, Zaza G, Riella LV, Cravedi P. COVID19 and the kidneys: an update. Front Med (Lausanne). 2020. https://doi.org/10.3389/fmed.2020.00423.

4. Puelles VG, Lütgehetmann M, Lindenmeyer MT, Sperhake JP, Wong MN, Allweiss L, et al. Multiorgan and renal tropism of SARS-CoV-2. N Engl J Med. 2020;383(6):590-2. https://doi.org/ 10.1056/NEJMc2011400.

5. Cheng Y, Luo R, Wang K, Zhang M, Wang Z, Dong L, et al. Kidney disease is associated with in-hospital death of patients with COVID-19. Kidney Int. 2020;97(5):829-38. https://doi.org/ 10.1016/j.kint.2020.03.005.

6. Henry BM, Lippi G. Chronic kidney disease is associated with severe coronavirus disease 2019 (COVID-19) infection. Int Urol Nephrol. 2020;52(6):1193-4. https://doi.org/10.1007/ s11255-020-02451-9.

7. Saunders H, (2020) D. S. Continuous renal replacement therapy. In: StatPearls I, editor

8. Baduashvili A, Oberle LP, Devitt J. Frequency of continuous renal replacement therapy use early in coronavirus disease 2019 pandemic. Crit Care Explor. 2020. https://doi.org/10.1097/CCE. 0000000000000129.

9. Moher D, Liberati A, Tetzlaff J, Altman DG. Preferred reporting items for systematic reviews and meta-analyses: the PRISMA statement. PLoS Med. 2009. https://doi.org/10.1371/journal. pmed.1000097.

10. Stroup DF, Berlin JA, Morton SC, Olkin I, Williamson GD, Rennie D, et al. Meta-analysis of observational studies in epidemiology: a proposal for reporting. Meta-analysis Of observational studies in epidemiology (MOOSE) group. JAMA. 2020;283(15):2008-12. https://doi.org/10.1001/jama.283.15. 2008.

11. Wells GA, Shea B,'Connell DO, Peterson J, Welch V, Losos M et al The newcastle-ottawa scale (NOS) for assessing the quality of nonrandomised studies in meta-analyses. http://www.ohri.ca/ programs/clinical_epidemiology/oxford.asp. Accessed 2020.

12. Huang C, Wang Y, Li X, Ren L, Zhao J, Hu Y, et al. Clinical features of patients infected with 2019 novel coronavirus in Wuhan. China Lancet. 2020;395(10223):497-506. https://doi.org/10.1016/ s0140-6736(20)30183-5. 
13. Guan WJ, Ni ZY, Hu Y, Liang WH, Ou CQ, He JX, et al. Characteristics of coronavirus disease 2019 in China. N Engl J Med. 2020. https://doi.org/10.1056/NEJMoa2002032.

14. Wang D, Hu B, Hu C, Zhu F, Liu X, Zhang J, et al. Clinical characteristics of 138 hospitalized patients with 2019 novel coronavirus-infected pneumonia in Wuhan. China JAMA. 2020;323(11):1061-9. https://doi.org/10.1001/jama.2020.1585.

15. Zhang JJ, Dong X, Cao YY, Yuan YD, Yang YB, Yan YQ, et al. Clinical characteristics of 140 patients infected with SARS-CoV-2 in Wuhan, China. Allergy. 2020;75(7):1730-41. https://doi.org/ 10.1111/all.14238

16. Yang X, Yu Y, Xu J, Shu H, Xia J, Liu H, et al. Clinical course and outcomes of critically ill patients with SARS-CoV-2 pneumonia in Wuhan, China: a single-centered, retrospective, observational study. Lancet Respir Med. 2020. https://doi.org/10.1016/s22132600(20)30079-5.

17. Mo P, Xing Y, Xiao Y, Deng L, Zhao Q, Wang H, et al. Clinical characteristics of refractory COVID-19 pneumonia in Wuhan. China Clin Infect Dis. 2020. https://doi.org/10.1093/cid/ciaa270.

18. Wang L, He W, Yu X, Hu D, Bao M, Liu H, et al. Coronavirus disease, 2019 in elderly patients: characteristics and prognostic factors based on 4-week follow-up. J Infect. 2020. https://doi.org/ 10.1016/j.jinf.2020.03.019.

19. Ruan Q, Yang K, Wang W, Jiang L, Song J. Clinical predictors of mortality due to COVID-19 based on an analysis of data of 150 patients from Wuhan. China Intensive Care Med. 2020;46(5):8468. https://doi.org/10.1007/s00134-020-05991-x.

20. Zhou F, Yu T, Du R, Fan G, Liu Y, Liu Z, et al. Clinical course and risk factors for mortality of adult inpatients with COVID19 in Wuhan, China: a retrospective cohort study. Lancet. 2020;395(10229):1054-62. https://doi.org/10.1016/S01406736(20)30566-3.

21. Chen G, Wu D, Guo W, Cao Y, Huang D, Wang H, et al. Clinical and immunological features of severe and moderate coronavirus disease 2019. J Clin Investig. 2020;130(5):2620-9. https://doi.org/ 10.1172/JCI137244.

22. Qin C, Zhou L, Hu Z, Zhang S, Yang S, Tao Y, et al. Dysregulation of immune response in patients with COVID-19 in Wuhan. China Clin Infect Dis. 2020. https://doi.org/10.1093/cid/ciaa248.

23. Zhao X-Y, Xu X-X, Yin H-S, Hu Q-M, Xiong T, Tang Y-Y, et al. Clinical characteristics of patients with 2019 coronavirus disease in a non-Wuhan area of Hubei Province, China: a retrospective study. BMC Infect Dis. 2020. https://doi.org/10.1186/ s12879-020-05010-w.

24. Goyal P, Choi JJ, Pinheiro LC, Schenck EJ, Chen R, Jabri A, et al. Clinical characteristics of covid-19 in New York City. N Engl J Med. 2020;382(24):2372-4. https://doi.org/10.1056/NEJMc20104 19.

25. Paranjpe I, Russak A, De Freitas JK, Lala A, Miotto R, Vaid A, et al (2020) Clinical characteristics of hospitalized Covid-19 patients in New York City. medRxiv https://doi.org/10.1101/2020. 04.19.20062117

26. Wan S, Xiang Y, Fang W, Zheng Y, Li B, Hu Y, et al. Clinical features and treatment of COVID-19 patients in northeast Chongqing. J Med Virol. 2020;92(7):797-806. https://doi.org/10.1002/ jmv.25783.

27. Zheng Y, Sun L-J, Xu M, Pan J, Zhang Y-T, Fang X-L, et al. Clinical characteristics of 34 COVID-19 patients admitted to intensive care unit in Hangzhou, China. J Zhejiang Univ Sci B. 2020;21(5):378-87. https://doi.org/10.1631/jzus.B2000174.

28. Hong KS, Lee KH, Chung JH, Shin KC, Choi EY, Jin HJ, et al. Clinical Features and outcomes of 98 patients hospitalized with SARS-CoV-2 infection in Daegu, South Korea: a brief descriptive study. Yonsei Med J. 2020;61(5):431-7. https://doi.org/10.3349/ ymj.2020.61.5.431.
29. Nowak B, Szymański P, Pańkowski I, Szarowska A, Życińska K, Rogowski W, et al. Clinical characteristics and short-term outcomes of patients with coronavirus disease 2019: a retrospective single-center experience of a designated hospital in Poland. Pol Arch Intern Med. 2020;130(5):407-11. https://doi.org/10.20452/ pamw.15361.

30. Mikami T, Miyashita H, Yamada T, Harrington M, Steinberg D, Dunn A, et al. Risk factors for mortality in patients with COVID19 in New York City. J Gen Intern Med. 2020. https://doi.org/10. 1007/s11606-020-05983-Z.

31. Kalyanaraman Marcello R, Dolle J, Grami S, Adule R, Li Z, Tatem K, et al. Characteristics and outcomes of COVID-19 patients in New York City's public hospital system. PLoS ONE. 2020. https://doi.org/10.1371/journal.pone.0243027.

32. Shahriarirad R, Khodamoradi Z, Erfani A, Hosseinpour H, Ranjbar K, Emami Y, et al. Epidemiological and clinical features of 2019 novel coronavirus diseases (COVID-19) in the South of Iran. BMC Infect Dis. 2020. https://doi.org/10.1186/ s12879-020-05128-X.

33. Wang Y, Liao B, Guo Y, Li F, Lei C, Zhang F et al (2020) Clinical characteristics of patients infected with the novel 2019 coronavirus (SARS-Cov-2) in Guangzhou, China. Open forum infectious diseases https://doi.org/10.1093/ofid/ofaa187

34. Zhang G, Hu C, Luo L, Fang F, Chen Y, Li J, et al. Clinical features and short-term outcomes of 221 patients with COVID-19 in Wuhan, China. J Clin Virol. 2020. https://doi.org/10.1016/j.jcv. 2020.104364.

35. Suleyman G, Fadel RA, Malette KM, Hammond C, Abdulla H, Entz A, et al. Clinical characteristics and morbidity associated with coronavirus disease 2019 in a series of patients in metropolitan detroit. JAMA Netw Open. 2020. https://doi.org/10.1001/ jamanetworkopen.2020.12270

36. Wang Y, Lu X, Li Y, Chen H, Chen T, Su N, et al. Clinical course and outcomes of 344 intensive care patients with COVID-19. Am J Respir Crit Care Med. 2020;201(11):1430-4. https://doi.org/10. 1164/rccm.202003-0736LE.

37. Li X, Xu S, Yu M, Wang K, Tao Y, Zhou Y, et al. Risk factors for severity and mortality in adult COVID-19 inpatients in Wuhan. J Allergy Clin Immunol. 2020;146(1):110-8. https://doi.org/10. 1016/j.jaci.2020.04.006.

38. Xu XW, Wu XX, Jiang XG, Xu KJ, Ying LJ, Ma CL, et al. Clinical findings in a group of patients infected with the 2019 novel coronavirus (SARS-Cov-2) outside of Wuhan, China: retrospective case series. BMJ. 2020. https://doi.org/10.1136/bmj.m606.

39. Ferguson J, Rosser JI, Quintero O, Scott J, Subramanian A, Gumma M, et al. Characteristics and outcomes of coronavirus disease patients under nonsurge conditions, Northern California, USA, march-april 2020. Emerg Infect Dis. 2020;26(8):1679-85. https://doi.org/10.3201/eid2608.201776.

40. Yang Q, Xie L, Zhang W, Zhao L, Wu H, Jiang J, et al. Analysis of the clinical characteristics, drug treatments and prognoses of 136 patients with coronavirus disease 2019. J Clin Pharm Ther. 2020;45(4):609-16. https://doi.org/10.1111/jcpt.13170.

41. Gabarre P, Dumas G, Dupont T, Darmon M, Azoulay E, Zafrani L. Acute kidney injury in critically ill patients with COVID-19. Intensive Care Med. 2020;46(7):1339-48. https://doi.org/10.1007/ s00134-020-06153-9.

42. Ronco C, Reis T. Kidney involvement in COVID-19 and rationale for extracorporeal therapies. Nat Rev Nephrol. 2020;16(6):308 10. https://doi.org/10.1038/s41581-020-0284-7.

43. Flythe JE, Assimon MM, Tugman MJ, Chang EH, Gupta S, Shah $\mathrm{J}$, et al. Characteristics and outcomes of individuals with preexisting kidney disease and COVID-19 admitted to intensive care units in the united states. Am J Kidney Dis. 2020. https://doi.org/ 10.1053/j.ajkd.2020.09.003. 
44. Nadim MK, Forni LG, Mehta RL, Connor MJ, Liu KD, Ostermann M, et al. COVID-19-associated acute kidney injury: consensus report of the 25th acute disease quality initiative (ADQI) workgroup. Nat Rev Nephrol. 2020;16(12):747-64. https://doi. org/10.1038/s41581-020-00356-5.

45. Shao M, Li X, Liu F, Tian T, Luo J, Yang Y. Acute kidney injury is associated with severe infection and fatality in patients with COVID-19: a systematic review and meta-analysis of 40 studies and 24,527 patients. Pharmacol Res. 2020. https://doi.org/10. 1016/j.phrs.2020.105107.

46. Yang X, Yu Y, Xu J, Shu H, Ja X, Liu H, et al. Clinical course and outcomes of critically ill patients with SARS-CoV-2 pneumonia in Wuhan, China: a single-centered, retrospective, observational study. Lancet Respir Med. 2020;8(5):475-81. https://doi.org/10. 1016/S2213-2600(20)30079-5.

47. Chen N, Zhou M, Dong X, Qu J, Gong F, Han Y, et al. Epidemiological and clinical characteristics of 99 cases of 2019 novel coronavirus pneumonia in Wuhan, China: a descriptive study. Lancet. 2020;395(10223):507-13. https://doi.org/10.1016/s01406736(20)30211-7.

48. Shang Y, Pan C, Yang X, Zhong M, Shang X, Wu Z, et al. Management of critically ill patients with COVID-19 in ICU: statement from front-line intensive care experts in Wuhan, China. Ann Intensive Care. 2020. https://doi.org/10.1186/ s13613-020-00689-1.

49. Raina R, Chakraborty R, Sethi SK, Bunchman T. kidney replacement therapy in COVID-19 induced kidney failure and septic shock: a pediatric continuous renal replacement therapy [PCRRT] position on emergency preparedness with resource allocation. Front Pediatr. 2020. https://doi.org/10.3389/fped.2020.00413.

50. Han F, Sun R, Ni Y, Hu X, Chen X, Jiang L, et al. Early initiation of continuous renal replacement therapy improves clinical outcomes in patients with acute respiratory distress syndrome. Am J Med Sci. 2015;349(3):199-205. https://doi.org/10.1097/ maj.0000000000000379.
51. Ankawi G, Neri M, Zhang J, Breglia A, Ricci Z, Ronco C. Extracorporeal techniques for the treatment of critically ill patients with sepsis beyond conventional blood purification therapy: the promises and the pitfalls. Crit Care. 2018. https://doi.org/10.1186/ s13054-018-2181-z.

52. Gaudry S, Hajage D, Benichou N, Chaibi K, Barbar S, Zarbock A, et al. Delayed versus early initiation of renal replacement therapy for severe acute kidney injury: a systematic review and individual patient data meta-analysis of randomised clinical trials. Lancet. 2020;395(10235):1506-15. https://doi.org/10.1016/ S0140-6736(20)30531-6.

53. Burgner A, Ikizler TA, Dwyer JP. COVID-19 and the inpatient dialysis unit. Clin J Am Soc Nephrol. 2020. https://doi.org/10. 2215/CJN.03750320.

54. Wang B, Luo Q, Zhang W, Yu S, Cheng X, Wang L, et al. The involvement of chronic kidney disease and acute kidney injury in disease severity and mortality in patients with COVID-19: a meta-analysis. Kidney Blood Press Res. 2020. https://doi.org/10. 1159/000512211.

55. Pranata R, Supriyadi R, Huang I, Permana H, Lim MA, Yonas $\mathrm{E}$, et al. The association between chronic kidney disease and new onset renal replacement therapy on the outcome of COVID-19 patients: a meta-analysis. Clin Med Insights Circ Respir Pulm Med. 2020. https://doi.org/10.1177/1179548420959165.

56. Robbins-Juarez SY, Qian L, King KL, Stevens JS, Husain SA, Radhakrishnan J, et al. Outcomes for patients with COVID-19 and acute kidney injury: a systematic review and meta-analysis. Kidney Int Rep. 2020;5(8):1149-60. https://doi.org/10.1016/j.ekir. 2020.06.013.

Publisher's Note Springer Nature remains neutral with regard to jurisdictional claims in published maps and institutional affiliations.

\section{Authors and Affiliations}

\section{Jagmeet Singh ${ }^{1}$. Preeti Malik ${ }^{2}$ - Nidhi Patel ${ }^{3}$. Suveenkrishna Pothuru ${ }^{4} \cdot$ Avantika Israni $^{5}$. Raja Chandra Chakinala ${ }^{6} \cdot$ Maryam Rafaqat Hussain $^{2} \cdot$ Anusha Chidharla $^{7} \cdot$ Harshil Patel $^{8} \cdot$ Saurabh Kumar Patel $^{9}$. Rizwan Rabbani ${ }^{10}$. Urvish Patel ${ }^{2}$. Savneek Chugh ${ }^{11}$. Asim Kichloo ${ }^{12}$}

Jagmeet Singh

Jsingh2483@gmail.com

Nidhi Patel

nhp38@drexel.edu

Suveenkrishna Pothuru

dr.skpothuru@gmail.com

Avantika Israni

Avantikaisrani1993@gmail.com

Raja Chandra Chakinala

rajachandra@gmail.com

Maryam Rafaqat Hussain

maryamhussain0325@gmail.com

Anusha Chidharla

anushaaedma@gmail.com

Harshil Patel

drharshilpatel@yahoo.in
Saurabh Kumar Patel

Drsaurabh.14@gmail.com

Rizwan Rabbani

drrizwanrabbani@gmail.com

Urvish Patel

dr.urvish.patel@gmail.com

Savneek Chugh

savneekchugh55@gmail.com

Asim Kichloo

kichlooasim@gmail.com

1 Geisinger Commonwealth School of Medicine, Scranton, PA, USA

2 Department of Public Health, Icahn School of Medicine At Mount Sinai, 1 Gustave L. Levy Pl, New York, NY, USA

3 Drexel University College of Medicine, Philadelphia, PA, USA

4 Ascension Via Christi Hospital, Manhattan, KS, USA 
5 St Mary Medical Center, Langhorne, PA, USA

6 Guthrie Robert Packer Hospital, Sayre, PA, USA

7 University of Illinois College of Medicine Peoria, Champaign, IL, USA

8 Ascension Providence Hospital/Michigan State University College of Human Medicine, East Lansing, USA
9 University of Illinois at Chicago, Chicago, IL, USA

10 Temple University, Philadelphia, PA, USA

11 New York Medical College, Hawthorne, NY, USA

12 College of Medicine, Central Michigan University, Saginaw, MI, USA 